\title{
ASUPAN KALSIUM DAN VITAMIN C DENGAN TINGGI BADAN SISWA SD NEGERI INPRES BERU-BERU KECAMATAN KALUKKU KABUPATEN MAMUJU
}

\author{
Hapzah $^{1}$, Supriandi ${ }^{2}$ \\ ${ }^{1}$ Jurusan Keperawatan Poltekkes Kemenkes Mamuju \\ ${ }^{2}$ Jurusan Gizi Poltekkes Kemenkes Mamuju
}

\begin{abstract}
The Primary School Children is a strategic objective to improve nutrition in the community because at this time the development of the child begins to form steady. The problem of stunting or short children can be affected by the lack of various nutrients, inadequate intake of nutrients such as protein, calcium and others will be at risk of child stunting or short. This type of research is descriptive. The sample in this study are as many as 65 people were obtained by purposive sampling. The intake of calcium and vitamin $\mathrm{C}$ taken with the formulir recall 24 hours, and the height was measured with use the microtoice. The results showed that there were $76.9 \%$ short of nutritional status (stunting) indicator of $\mathrm{TB} / \mathrm{U}$, there are $100 \%$ of children who have a calcium intake of less, and $96.9 \%$ were vitamin $\mathrm{C}$ intake less.
\end{abstract}

\section{Keyword: calcium, vitamin C, primary school children, nutritional status}

\section{PENDAHULUAN}

Tercapainya pembangunan nasional dibutuhkan antara lain tersedianya sumber daya manusia yang tangguh, mandiri dan berkualitas. Perhatian terhadap dunia kehidupan anak-anak tidak dapat diabaikan karena anak-anak merupakan modal dalam pembangunan, mengingat anak-anak masih dalam proses pertumbuhan, dan perkembangan, baik jasmaniah, rohaniah, maupun sosial. Salah satu upaya peningkatan pertumbuhan dan perkembangan anak adalah perbaikan gizi. Gizi yang baik akan menghasilkan sumber daya manusia yang berkualitas (Pradanti, M, \& K, 2015).

Masalah gizi buruk-kurang di Indonesia masih merupakan masalah kesehatan masyarakat prevalensi tinggi. Diantara 33 provinsi, terdapat tiga provinsi termasuk kategori prevalensi sangat tinggi, yaitu Sulawesi Barat, Papua Barat dan Nusa Tenggara Timur. Di Sulawesi Barat prevalensi gizi buruk-kurang menurut indikator $\mathrm{BB} / \mathrm{U}$ sebesar $\geq 30 \%$, dan prevalensi gizi kurang menurut indikator $\mathrm{TB} / \mathrm{U}$ sebesar $\geq 50 \%$, sedangkan menurut WHO (2010) prevalensi sangat tinggi jika $\geq 30$ persen (Riskesdes, 2013).

Perbaikan gizi diperlukan mulai dari masa kehamilan, bayi dan anak balita, prasekolah, anak usia sekolah dasar, remaja dan dewasa, sampai usia lanjut. Anak sekolah dasar merupakan sasaran strategis dalam perbaikan gizi masyarakat karena pada masa anak fungsi organ otak mulai terbentuk mantap sehingga perkembangan kecerdasan cukup pesat. Anak Sekolah Dasar (SD) adalah anak usia 6 - 12 tahun (Dewi, 2015).

Anak usia sekolah dasar dapat dikatakan sebagai anak berumur 6-12 tahun yang merupakan masa emas yang kedua dengan karakteristik masa pertumbuhan yang relatif tetap. Anak ini tumbuh dengan kecepatan genetik masing-masing dengan perbedaan tinggi badan yang sudah mulai tampak. Masalah stunting atau anak yang pendek dapat dipengaruhi oleh kekurangan berbagai macam zat gizi, tidak cukupnya asupan zat gizi tersebut seperti protein, kalsium dan lain-lain akan beresiko terjadinya stunting atau anak yang pendek (Hardinsyah, Damayanthi, \& Zulianti, 2008).

Vitamin C merupakan vitamin yang berfungsi selain antioksidan tetapi juga mampu memproduksi kolagen. Kolagen adalah senyawa turunan protein yang mampu menghubungkan jaringan di dalam tubuh termasuk jaringan tulang, sehingga dalam proses penyembuhan patah tulang pun sangat membutuhkan kerja dari senyawa kolagen ini. Disamping itu vitamin $\mathrm{C}$ mampu meningkatkan penyerapan kalsium oleh tubuh. (Almatsier, 2004). Menurut hasil penelitian Dewi (2015), 
kontribusi asupan vitamin C anak SD pada umumnya kurang yaitu sebanyak $(88,9 \%)$.

Penelitian ini bertujuan untuk mengidentifkasi asupan kalsium dan vitamin C dengan tinggi badan anak Sekolah Dasar.

\section{METODE}

\section{Jenis Penelitian}

Jenis Penelitian ini adalah deskriptif yaitu mengidentifikasi asupan kalsium dan vitamin C dengan tinggi badan anak Sekolah Dasar.

\section{Lokasi dan Waktu Penelitian}

Lokasi penelitian dilaksanakan di SD Negeri Inpres Beru-Beru Kecamatan Kalukku Kabupaten Mamuju pada tahun 2015.

\section{Populasi dan Sampel}

Populasi penelitian adalah seluruh anak SD Negeri Inpres Beru-Beru Kalukku yang berjumlah 143 orang. Sampel dalam penelitian ini adalah murid kelas 4 sampai kelas $6 \mathrm{SD}$

Inpres Beru-Beru yang berjumlah 65 orang, diambil dengan cara purposive sampling.

\section{Teknik Pengumpulan Data}

Variabel yang diukur antara lain asupan kalsium, vitamin C, dan tinggi badan. Data Asupan kalsium dan vitamin $\mathrm{C}$ diperoleh dengan menggunakan formulir recall 24 jam. Adapun data Tinggi badan diperoleh dengan melakukan pengukuran tinggi badan dengan meggunakan microtoice.

\section{Pengolahan dan Penyajian Data}

Data recall 24 jam diolah dengan menggunakan menu A lalu membandingkan dengan AKG 2004 sedangkan data tinggi badan diolah dengan menggunakan program nutria 2008 dengan indikator TB/U. Data disajikan dalam bentuk tabel dan narasi.

\section{HASIL PENELITIAN}

Tabel 1. Distribusi Responden berdasarkan Status Gizi Menurut Indikator TB/U, Asupan Kalsium dan Vitamin C di SD Inpres Beru-Beru Kecamatan Kalukku Kabupaten Mamuju Tahun 2015

\begin{tabular}{ccc}
\hline Variabel & Jumlah & \% \\
\hline Status gizi TB/U & & \\
Normal & 15 & 23,1 \\
Pendek & 50 & 76,9 \\
\hline Asupan kalsium & & \\
Kurang & 65 & 100 \\
\hline Asupan vitamin C & & \\
Baik & 2 & 3,1 \\
Kurang & 63 & 96,9 \\
\hline
\end{tabular}

Hasil penelitian menunjukkan bahwa terdapat lebih banyak anak yang memiliki status gizi pendek yaitu sebanyak $50(76,9 \%)$ daripada anak yang memiliki status gizi normal berdasarkan indikator tinggi badan menurut umur yaitu sebanyak 15 (23,1 \%). Semua anak (100 \%) memiliki asupan kalsium yang kurang. Hasil penelitian juga menunjukkan bahwa terdapat lebih banyak anak dengan asupan vitamin C kurang yaitu sebanyak $63(96,9)$ daripada anak yang memiliki asupan vitamin $\mathrm{C}$ baik yaitu sebanyak $2(3,1 \%)$. Hal ini dapat dilihat pada Tabel 1.
Hasil penelitian menunjukkan bahwa terdapat jumlah yang sama antara anak yang memiliki status gizi normal yaitu sebanyak 1 $(1,5 \%)$ dengan anak yang memiliki status gizi pendek berdasarkan indikator tinggi badan menurut umur yaitu sebanyak $1(1,5 \%)$ dari 2 anak yang memiliki asupan vitamin $\mathrm{C}$ baik. Kemudian terdapat lebih banyak anak yang memiliki satus gizi pendek yaitu sebanyak 49 $(75,4 \%)$ daripada anak yang memiliki status gizi normal berdasarkan indikator tinggi badan menurut umur yaitu sebanyak $14(21,5 \%)$ dari 63 anak yang memiliki asupan vitamin $C$ yang kurang. Hal ini dapat dilihat pada Tabel 2. 
Tabel 2. Distribusi Responden berdasarkan Asupan Vitamin C terhadap Status Gizi menurut Indikator TB/U di SD Inpres Beru-Beru Kecamatan Kalukku Kabupaten Mamuju Tahun 2015

\begin{tabular}{cccccccc}
\hline & \multicolumn{4}{c}{ Status gizi TB/U } & \multicolumn{3}{c}{ Total } \\
\cline { 2 - 6 } vitamin C & \multicolumn{3}{c}{ Normal } & \multicolumn{2}{c}{ Pendek } & & \\
\cline { 2 - 7 } & $\mathbf{n}$ & $\%$ & $\mathbf{n}$ & $\%$ & $\mathbf{n}$ & $\%$ \\
\hline Baik & 1 & 1,5 & 1 & 1,5 & 2 & 3,1 \\
Kurang & 14 & 21,5 & 49 & 75,4 & 63 & 96,9 \\
\hline Total & 15 & 23,1 & 50 & 76,9 & 65 & 100 \\
\hline
\end{tabular}

\section{PEMBAHASAN}

Kalsium merupakan mineral yang paling banyak terdapat dalam tubuh. Sekitar 99 $\%$ kalsium berada di dalam jaringan keras, yaitu tulang dan gigi terutama dalam bentuk hidroksiapatit. Densitas tulang berbeda menurut umur, meningkat pada bagian pertama kehidupan dan menurun secara berangsur setelah dewasa (Almatsier, 2004). Tinggi badan merupakan ukuran antropometri yang menggambarkan keadaan skeletal (Supariasa, 2012).

Hasil penelitian menunjukkan bahwa lebih banyak anak yang memiliki status gizi pendek daripada yang berstatus gizi normal berdasarkan indikator tinggi badan menurut umur yaitu sekitar 50 (76,9 \%) anak. Menurut WHO prevalensi sangat tinggi jika $\geq 30 \%$. Hal ini menunjukkan bahwa prevalensi stunting anak SD Negeri Beru-Beru yang sangat tinggi. Hasil penelitian ini sejalan dengan hasil Riskesdes (2013) yang menyatakan bahwa Sulawesi Barat merupakan salah satu provinsi yang memiliki prevalensi stunting (pendek) sangat tinggi yaitu sebanyak $\geq 50 \%$ dari 2 provinsi lainnya yaitu Nusa Tenggara Timur dan Papua Barat. Hasil penelitian juga menunjukkan bahwa lebih banyak anak yang memiliki status gizi pendek daripada anak yang memiliki status gizi normal dari 65 anak yang memiliki asupan kalsium kurang. Hal ini sejalan dengan teori yang menyatakan bahwa tinggi badan dapat dipengaruhi oleh beberapa faktor antara lain asupan kalsium, faktor genetik, hormon pertumbuhan, ketersedian vitamin $\mathrm{D}$, dan aktifitas fisik dan olah raga. Menurut anderson (2004) menyatakan bahwa faktor genetik menentukan sekitar $60 \%$ pertumbuhan tulang, sehingga sekitar $40 \%$ ditentukan oleh faktor lingkungan. Asupan kalsium merupakan salah satu dari faktor lingkungan (Soetjiningsih, 1995).

Tubuh yang sehat akan selalu mempertahankan kalsium pada batas normal. Inilah yang disebut "homeostatis kalsium". Jika dari pola makan unsur kalsium tidak mencukupi, maka tubuh mempunyai cara-cara untuk menjaga agar kalsium darah tidak menurun, yaitu dengan mengandalkan peran hormon kalsitonin, hormon anak gondok, dan vitamin D (Artuti, 2011).

Hasil penelitian ini sejalan dengan hasil penelitian Nainggolan (2014) dengan judul hubungan pola konsumsi makanan dan konsumsi susu dengan tinggi badan anak usia 612 tahun, yang menyatakan bahwa masih terdapat anak yang pendek yaitu sebanyak $16,7 \%$ anak, dan $1,7 \%$ anak sangat pendek. Hasil penelitian ini juga menunjukkan adanya hubungan antara kecukupan konsumsi energi dan kalsium dari susu dengan tinggi badan anak SD usia 6-12 tahun dari 60 sampel. Sedangkan hasil penelitian Ramayulis (2008) menunjukkan bahwa Sebanyak 76,2\% remaja mengkonsumsi kalsium kurang dari $75 \%$ AKG.

Hasil penelitian ini menunjukkan bahwa dari 63 anak yang memiliki asupan vitamin $\mathrm{C}$ kurang terdapat lebih banyak anak yang memiliki status gizi pendek daripada yang berstatus gizi normal menurut indikator tinggi badan menurut umur. Vitamin $\mathrm{C}$ adalah vitamin yang mudah larut dalam air. Vitamin $\mathrm{C}$ cukup stabil dalam keadaan kering tetapi mudah rusak dalam keadaan larut, vitamin $\mathrm{C}$ mudah rusak karena bersentuhan dengan udara (oksidasi) terutama bila terkena panas. Oksidasi dipercepat dengan kehadiran tembaga dan besi. Vitamin C tidak stabil dalam larutan alkali, tetapi cukup stabil dalam larutan asam. Vitamin $\mathrm{C}$ adalah vitamin yang paling labil (Almatsier, 2004). 
Vitamin C merupakan vitamin yang berfungsi selain antioksidan tetapi juga mampu memproduksi kolagen. Kolagen adalah senyawa turunan protein yang mampu menghubungkan jaringan di dalam tubuh termasuk jaringan tulang, sehingga dalam proses penyembuhan patah tulang pun sangat membutuhkan kerja dari senyawa kolagen ini. Disamping itu vitamin C mampu meningkatkan penyerapan kalsium oleh tubuh dengan menjaga agar kalsium berada dalam bentuk larutan (Almatsier, 2004).

Vitamin C juga dapat meningkatkan daya tahan tubuh terhadap infeksi, kemungkinan karena pemeliharaan terhadap membran mukosa atau pengaruh terhadap fungsi kekebalan. Asupan vitamin C yang kurang bisa mempengaruhi fungsi kekebalan tubuh yang kurang sehingga anak mudah sakit. Anak yang sering sakit akan berpengaruh terhadap status gizi yang kurang, termasuk status gizi anak berdasarkan indikator tinggi badan menurut umur. Hasil penelitian Jayani (2014) yang berjudul hubungan antara penyakit infeksi dengan status gizi pada balita di Puskesmas Jambon Kecamatan Jambon Kabupaten Ponorogo tahun 2014 bahwa terdapat hubungan antara penyakit infeksi dengan status gizi Balita.

\section{KESIMPULAN}

Hasil penelitian ini menunjukkan bahwa terdapat lebih banyak anak yang memiliki status gizi pendek daripada anak yang berstatus gizi normal berdasarkan indikator tinggi badan menurut umur. Hasil penelitian juga menunjukkan bahwa terdapat lebih banyak anak berstatus gizi pendek daripada anak yang memiliki status gizi normal berdasarkan indikator tinggi badan menurut umur dari anak yang memiliki asupan vitamin $\mathrm{C}$ kurang. Adapun Asupan kalsium menunjukkan semuanya kurang.

\section{UCAPAN TERIMA KASIH}

Terima kasih disampaikan kepada Direktur Poltekkes Kemenkes Mamuju atas dukungannya terhadap penerbitan jurnal penelitian ini, kepada Kepala sekolah SD Negeri Inpres Beru-Beru Kecamatan Kalukku atas pemberian ijin dan bantuannya selama penelitian, serta ucapan terima kasih khususnya kepada anak-anak SD Negeri Inpres Beru-Beru Kecamatan Kalukku atas keikutsertaannya dalam penelitian ini sampai selesai.

\section{DAFTAR PUSTAKA}

Almatsier, S. (2004). Prinsip Dasar Ilmu Gizi. Jakarta: PT Gramedia Pustaka Utama.

Artuti, M. (2011). http://repository.usu.ac.id /bitstream/123456789/28149/4/Chapter $\% 20 I I . p d f$.

Dewi, R. (2015). Hubungan Kecukupan Zat Gizi Mikro terhadap Status Gizi Anak di SD Negeri Pabelan 1 Kartasura. Skripsi Program Studi Ilmu Gizi Fakultas Ilmu Kesehatan Universitas Muhammadiyah Surakarta.

Hardinsyah, Damayanthi, \& Zulianti. (2008). Hubungan Konsumsi Susu dan dan Kalsium dengan Densitas Tulang dan Tinggi Badan Remaja. Jurnal Gizi dan Pangan, volume 3 (1): hal $43-48$.

Jayani. (2014). Hubungan Antara Penyakit Infeksi Dengan Status Gizi Pada Balita Di Puskesmas Jambon Kecamatan Jambon Kabupaten Ponorogo Tahun 2014. Jurnal Gizi.

Nainggolan. (2014). Hubungan Pola Konsumsi Makanan dan Konsumsi Susu dengan Tinggi Badan Anak Usia 6-12 tahun. Skripsi Fakultas Kesehatan Masyarakat Universitas Sumatera Utara.

Pradanti, M., M, W., \& K, S. (2015). Hubungan Asupan Zat Besi (Fe) dan Vitamin C dengan Kadar Hemoglobin pada Siswi Kelas VIII SMP Negeri 3 Brebes. Jurnal Gizi Universitas Muhammadiyah Semarang, volume 4, nomor 1.

Ramayulis, R. (2008). Hubungan Asupan Vitamin, Mineral dan Rasio Asupan Kalsium dan Fosfor dengan Kepadatan Mineral Tulang Kalkaneus Wanita Muda, etd. repository.ugm.ac.id/index. php?mod=penelitian... Penelitian Detail \& act... ).

RI, B. P. (2013). Laporan Riskesdas tahun 2013.

Soetjiningsih. (1995). Tumbuh Kembang Anak. Jakarta: Penerbit Buku Kedokteran EGC. Supariasa. (2012). Penilaian Status Gizi. Jakarta: Penerbit Buku Kedokteran EGC. 